\title{
The frequency of bone fractures among patients with chronic kidney disease not on dialysis: two-year follow-up
}

\author{
ANDREJA FIGUREK, VLASTIMIR VLATKOVIC, DRAGAN VOJVODIC, BRANISLAV GASIC, MILORAD GRUJICIC \\ Clinic for Internal Diseases, Department for Nephrology, University Clinical Centre of the Republic of Srpska, \\ Banja Luka, Republic of Srpska, Bosnia and Herzegovina
}

\begin{abstract}
Introduction. Renal osteodystrophy is a severe complication of chronic kidney disease (CKD) that increases morbidity and mortality in these patients. Mineral and bone disorder starts early in CKD and affects the incidence of bone fractures. The aim of this study was to observe the frequency of diverse bone fractures in patients with CKD not on dialysis.

Methods. This cohort study included 68 patients that were followed during the two-year period. The patients were divided into two cohorts: one that developed bone fractures and the other that did not. There were $35(51.5 \%)$ men and $33(48.5 \%)$ women. The mean age of patients ranged $62.88 \pm 11.60$ years. During follow-up serum values of chronic kidney disease - mineral and bone indicators were measured. The methods of descriptive and analytical statistics were used in order to analyze obtained data.

Results. During this two-year follow-up seven patients developed bone fractures. Among them, females dominated ( 6 patients) compared to males (only 1 patient). The most common were fractures of forearm. The mean level of parathyroid hormone (PTH) at the beginning of the monitoring was higher in the group of patients with bone fractures $(165.25 \pm 47.69 \mathrm{pg} / \mathrm{mL})$ in regard to another group $(103.96 \pm 81.55 \mathrm{pg} / \mathrm{mL})$. After two-year follow-up, this difference became statistically significant at the level $p<0.05$. Patients that developed bone fractures had higher FRAX (Fracture Risk Assessment) score compared to another group.

Conclusion. In our study, about $10 \%$ of patients had bone fractures in the two-year follow-up period. Patients who developed fractures had a higher PTH level and FRAX score.
\end{abstract}

Key words: chronic kidney disease, mineral and bone disorder, fracture, renal osteodystrophy, bone.

\section{INTRODUCTION}

It is known that $5-10 \%$ of the world population has chronic kidney disease (CKD) [1], which is associated with many complications including bone disorders and fractures [2]. Renal osteodystrophy is a severe complication of chronic kidney disease that increases morbidity and mortality in these patients. Renal osteodystrophy (ROD) consists of the following group of disorders: a high bone turnover disease (usually associated with secondary hyperparathyroidism), a low bone turnover disease (includes adynamic bone disease, osteomalacia, and aluminum bone disease) and mixed uraemic osteodystrophy [3]. Mineral and bone disorder (CKDMBD), that includes ROD, vascular calcifications and mineral disturbances, starts early in CKD and affects the incidence of bone fractures. In a study performed by Hamdy et al., $75 \%$ of pre-dialysis CKD patients had abnormal bone histology (74\% osteitis fibrosa, $19 \%$ mixed bone disease, $1 \%$ osteomalacia, $1 \%$ aluminium bone disease, $5 \%$ a dynamic bone disease), without clinical, biochemical or radiographic evidence of bone disease [4]. Factors that predispose to low bone mineral density (BMD) in patients with CKD are age, gender, the onset of menopause, sedentary life style, low calcium intake, vitamin-D deficiency and hyperparathyroidism [5].

Bearing in mind the early beginning of CKD$\mathrm{MBD}$, as well as the possible bone fractures that aggravate life in these patients, the aim of this study was to observe the frequency of diverse bone fractures in patients with chronic kidney disease not on dialysis.

\section{MATERIAL AND METHODS}

The total of 68 patients was followed at regular controls at outpatient nephrology clinic during the two-year period. There were 35 (51.5\%) men and $33(48.5 \%)$ women. The mean age of patients ranged $62.88 \pm 11.60$ years. The methods of descriptive and analytical statistics were used in order to evaluate the obtained results. For statistical analysis and graphical data presentation we used IBM SPSS Statistics 22.0 program for Windows. The study protocol was approved by the Ethical Committee of the University Clinical Centre of the Republic of Srpska under number 01-9-153.2/14. 
Most patients belong to early CKD stage (1-3), and minority have advanced CKD (stage 4 and 5). This distribution of patients is the effect of outpatient clinic population.

\section{RESULTS}

During this two-year follow-up seven patients developed bone fractures, which is $10 \%$ of the observed population. Among them, females dominated (6 patients) compared to males (only 1 patient). Table 1 shows mean values of CKD-MBD parameters and kidney function in both patients groups. The mean level of parathyroid hormone (PTH) at the beginning of the monitoring was higher in the group of patients with bone fractures $(165.25 \pm$ $47.69 \mathrm{pg} / \mathrm{mL}$ ) in regard to the patients that did not had fractures $(103.96 \pm 81.55 \mathrm{pg} / \mathrm{mL})$. PTH serum levels raised during two years in patients that developed bone fractures, despite the use of vitamin D therapy (Fig. 1). Although there was no significant difference between PTH levels at the beginning between the two groups, T-test analysis revealed a statistically significant difference between PTH values after two-year follow-up $(p<0.05)$.

The average values of total alkaline phosphatase (ALP) serum levels at the beginning of the monitoring was higher in patients that developed bone fractures than in the other group, but without statistically significant difference. Both groups were uniform regarding kidney function, acid-base status and mineral level (Table 1).

When it is about the relationship between the frequency of bone fractures and CKD stage, we have seen that bone fractures were most frequently presented in CKD stage 1, 3 and 4 (Fig. 2).
The most common were fractures of forearm that appeared in 4 patients. Other fractures were: hip-fracture (one patient), upper arm fracture (one patient), lower leg fracture (one patient). We have compared CKD-MBD indicators in each group of patients.

Risk factors for bone fractures were also evaluated (Table 2). In the group of patients with bone fractures, $28 \%$ had diabetes mellitus, whereas $35 \%$ of patients had DM in the other group. Neither patient used corticosteroid therapy in the group with bone fractures. On the other hand, $15 \%$ of patients that have not developed bone fractures still have used corticosteriod therapy. Vitamin D supplementation had $43 \%$ in the first and $20 \%$ in the second group. Bearing in mind a relatively small sample and a quite short follow-up period for a course of CKD, these results must be taken with a grain of salt.

No patient had non-calcium based phosphate binder in each group. When it is about the use of bisphosphonate, only one patient in the group without bone fractures had this therapy.

In order to compare the risk of bone fractures among the patients groups, we have calculated FRAX (Fracture Risk Assessment) for ten-year probability of bone fractures, expressed as major osteoporotic fracture risk percentage and hip fracture risk percentage [6] and compared it to the actual bone fracture development. As depicted in Table 3, both the percentage of major osteoporotic fracture risk and the hip fracture risk were higher in the group of patients that developed bone fractures ( $9.24 \%$ and $1.99 \%$, respectively) compared to the group without bone fractures $(7 \%$ and $1.49 \%$, respectively). However, there was no statistically significant difference between the patients groups.

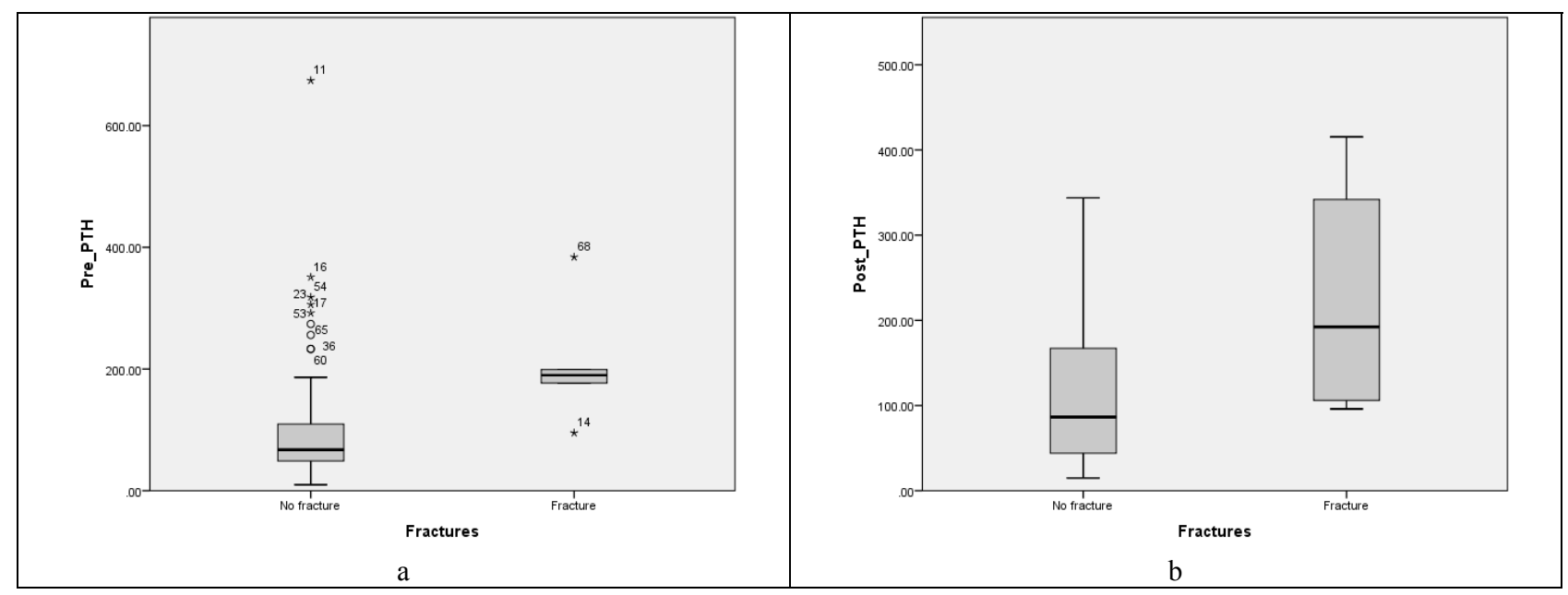

Figure 1. Analysis of parathyroid hormone (PTH) levels according to bone fractures development. x-axis: the groups of chronic kidney disease patients with or without bone fractures.1a- pre-PTH (y-axis): PTH levels at the beginning of the study. 1b- post-PTH (y-axis): PTH levels after two-year follow-up. 
Table 1

CKD-MBD parameters in both groups of patients

\begin{tabular}{|l|c|c|c|}
\hline \multicolumn{1}{|c|}{ Average values } & $\begin{array}{c}\text { Patients with } \\
\text { fractures }\end{array}$ & $\begin{array}{c}\text { Patients without } \\
\text { fractures }\end{array}$ & p-value \\
\hline PTH at start $(\mathrm{pg} / \mathrm{mL})$ & $165.25 \pm 47,69$ & $103.96 \pm 81,55$ & 0.07 \\
\hline PTH after follow-up & $265.75 \pm 149.56$ & $116.51 \pm 87.37$ & 0.01 \\
\hline ALP at start $(\mathrm{U} / \mathrm{L})$ & $113.00 \pm 54.40$ & $90.40 \pm 46.30$ & 0.33 \\
\hline Calcium $(\mathrm{mmol} / \mathrm{L})$ & $2.49 \pm 0.25$ & $2.36 \pm 0.18$ & 0.58 \\
\hline Phosphate $(\mathrm{mmol} / \mathrm{L})$ & $1.31 \pm 0.27$ & $1.18 \pm 0.29$ & 0.51 \\
\hline Sodium $(\mathrm{mmol} / \mathrm{L})$ & $144.56 \pm 6.70$ & $144.17 \pm 5.57$ & 0.46 \\
\hline Serum $\mathrm{Cr}(\mu \mathrm{mol} / \mathrm{L})$ & $159.57 \pm 75.91$ & $154.6 \pm 97.17$ & 0.88 \\
\hline eGFR $\left(\mathrm{mL} / \mathrm{min} / 1.73 \mathrm{~m}^{2}\right)$ & $38.57 \pm 25.26$ & $47.18 \pm 21.50$ & 0.41 \\
\hline ABE & $-3.17 \pm 3.49$ & $-1.41 \pm 2.67$ & 0.52 \\
\hline
\end{tabular}

Abbreviations: PTH - parathyroid hormone, ALP - alkaline phosphatase, $\mathrm{Cr}$ - creatinine, eGFR - estimated glomerular filtration rate, ABE - acid-base excess, CKD-MBD - chronic kidney disease mineral and bone disorder. Data are presented as mean \pm standard deviation. $p$-value statistically significant at the level $<0.05$.

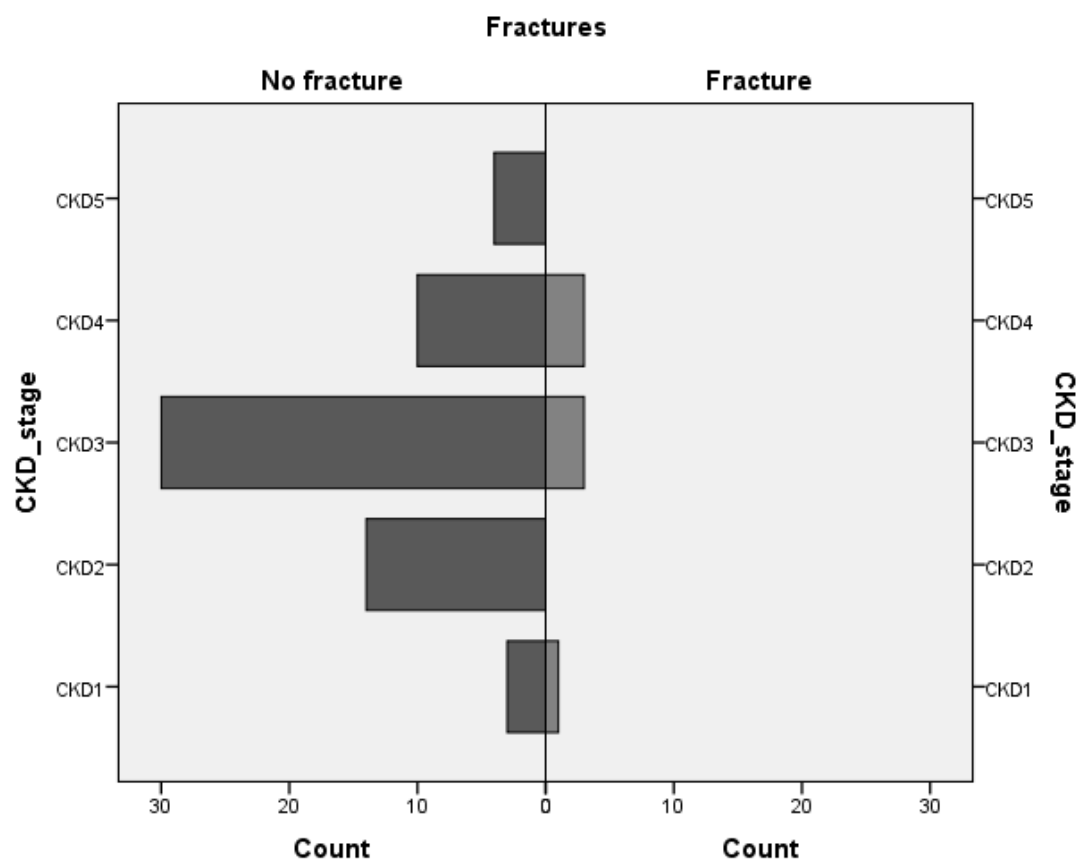

Figure 2. Frequency of bone fractures according to the stage of chronic kidney disease (CKD). Patients in CKD stage 1, 3 and 4 developed bone fractures in two-year follow-up. $\mathrm{x}$-axis - number of patients, $\mathrm{y}$-axis - stage of CKD.

Table 2

Evaluation of risk factors for bone fractures

\begin{tabular}{|c|c|c|}
\hline Risk factors & Patients with fractures & Patients without fractures \\
\hline Diabetes & 2 of $7(28 \%)$ & 21 of $61(35 \%)$ \\
\hline Corticosteroids & none & 9 of $61(15 \%)$ \\
\hline Vitamin D therapy & 3 of $7(43 \%)$ & 12 of $61(20 \%)$ \\
\hline Therapy & Patients with fractures & Patients without fractures \\
\hline Sevelamer & none & none \\
\hline Bisphosphonates & none & 1 of 61 \\
\hline
\end{tabular}

Table 3

Fracture risk assessment (FRAX) in patients with chronic kidney disease

\begin{tabular}{|l|c|c|c|}
\hline $\begin{array}{c}\text { FRAX } \\
\text { ten-year probability of bone } \\
\text { fractures }\end{array}$ & $\begin{array}{c}\text { Patients with } \\
\text { bone fractures }\end{array}$ & $\begin{array}{c}\text { Patients without } \\
\text { bone fracture }\end{array}$ & $\boldsymbol{p}$-value \\
\hline Major osteoporotic fracture (\%) & 9.24 & 7.00 & 0.24 \\
\hline Hip fracture (\%) & 1.99 & 1.49 & 0.47 \\
\hline
\end{tabular}




\section{DISCUSSION}

World Health Organization (WHO) defined six risk factors for bone fractures that are independent of bone mineral density (BMD): age, female gender, weight, Caucasian race, prior fracture and glucocorticoid use [7]. Patients on dialysis have about four times higher risk of hip fractures than individuals in the general population [8]. Analyzing the hip fracture in patients on hemodialysis, Coco et al. found that albumin, PTH, ALP and age were independent predictors [9]. In our study, among patients that developed bone fracture females dominated and all patients were Caucasians. The use of glucocorticoid therapy was not present in patients that developed bone fractures, unlike the other group that, however, took small doses of corticosteroid therapy.

Patients with CKD who do not have endstage renal disease have an increased risk of bone fracture [10]. Our study confirms this fact showing that during two-year follow-up the frequency of bone fractures was high $(10 \%)$.

Although it has been reported that diabetes presents a risk factor for hip fracture [11], we have not seen that patients with diabetes have higher risk of bone fracture. Study performed by Deyl et al. showed that in patients with primary glomerular disease, taking alfacalcidiol or lanthanum were associated with decreased risk of bone fractures [12]. However, the group of our patients that developed bone fractures had higher percentage than those taking vitamin D therapy.

Ayus et al. reported that mild prolonged chronic hyponatremia is independently associated with hip fracture risk in the elderly population with the low absolute risk [13]. There was no difference in sodium levels between the two groups of our study population.

In CKD patients not on dialysis, the prevalence of low BMD is much higher at the onethird radius site $(33 \%)$ than at either the lumbar spine $(19 \%)$ or the femoral neck (26\%) [14]. Russo et al. showed selective loss of cortical bone in patients on hemodialysis using peripheral quantitative computed tomography (QCT) (radius and tibia) [15]. Jamal et al. reported that peripheral QCT of the distal radial cortical compartment was superior to Dual-energy X-ray absorptiometry (DEXA) measurements of hip BMD to predict prevalent fracture [16]. Indeed, our study showed that in patients not on dialysis, the most common were fractures of the forearm.
BMD by dual-energy X-ray absorptiometry (DEXA) is unlikely to be sensitive or specific to either diagnose or differentiate osteoporosis from other disorders of ROD [3]. In patients with CKD stages 1-3, WHO DEXA criteria can be used for diagnosing osteoporosis if there is normal serum bone biochemistry [1]. But in patients with CKD stages 4 and 5, it is the best to exclude ROD with quantitative bone histomorphometry [3]. Therefore, KDIGO recommended that BMD testing should not be performed routinely in patients with CKD stages 3-5, because BMD does not predict fracture risk in CKD patients as well as in the general population, and, also, BMD does not predict the type of renal osteodystrophy [1]. Hence, we did not consider to perform DEXA scan in our patients. However, we have calculated FRAX score without BMD, which was higher in the group of patients with bone fractures. The possible explanation of the absence of statistical significance could be the two-year follow-up period of our patients compared to ten-year risk period that is predicted by FRAX score.

The relationship between higher ALP and fracture could be explained due to high bone turnover [17] and it is recommended to routine measure serum ALP in the treatment of chronic kidney disease-mineral and bone disorder (CKDMBD) [1]. ALP is primary secreted by the liver and bone, and small amounts are secreted by kidneys, intestine and leukocytes [18]. Therefore, it is better to monitor bone-specific ALP (BALP) in the monitoring of bone mineral metabolism [19]. Maruyama et al. found that higher serum alkaline phosphatase (ALP) levels were independently associated with mortality as well as with the incidence of hip fracture in Japanese hemodialysis patients [18]. In a study performed by Park and colleagues serum ALP negatively correlated with bone mineral density assessed by dual-energy $\mathrm{X}$-ray absorptiometry in hemodialysis patients [20]. Higher serum ALP levels are associated with increased risk of mortality in hemodialysis patients [21], and also in patients not on dialysis [22]. In our patients, the average value of ALP at the beginning of the monitoring was slightly higher in the group of patients that developed bone fractures, but remained in reference range.

Compared to serum PTH, which has a U-shaped or J-shaped association with mortality, serum ALP seems to have a linear and incremental association [18]. Coco et al. found a higher risk of hip fractures in patients with lower PTH levels 
$(<195)$ [9]. Jadoul et al. highlighted that patients with PTH levels $>900$ had elevated risk of any new fracture versus patients with PTH 150-300 (DOPPS study) [23]. However, maintaining the normal serum PTH level in CKD stages 4 and 5 may predispose to low bone turnover disease [24]. Extreme serum values of parathyroid hormone (PTH) and bone specific alkaline phosphatase (BALP) are helpful to distinguish between low and high turnover disease [25]. Iimori et al. found association between serum BALP and any type of incident fracture and that a significant greater risk of any type of incident fracture was associated with PTH levels $<150$ or $>300 \mathrm{pg} / \mathrm{mL}$ [26]. Our study showed that patients with bone fractures had higher PTH level with the trend of increasing during twoyear follow-up and with a statistically significant difference between groups after the follow-up period.

When it is about osteoporosis treatment, it should be noted that bisphosphonates are predominantly dependent on renal clearance [27]. Their intravenous application can be nephrotoxic [28]. Also, antiresorptives can cause a risk for low turnover bone disease [29]. Even though there are not enough data about safety of the use of antiresorptives in patients with CKD stage 5, bisphosphonates may be considered in those patients with fractures after exclusion of adynamic bone disease and osteomalacia by undertaking a bone biopsy [3]. In the group of patients that did not develop fractures, one patient had bisphosphonate therapy, but due to this small number, the correlation could not be performed.

Also, supplementation vitamin D therapy must not be forgotten. Levin et al. performed a study in which $13 \%$ of patients with eGFR $\geq 80$ already had low serum concentrations of $1,25(\mathrm{OH})_{2} \mathrm{D}$ and $12 \%$ patients had high serum concentrations of PTH [30]. In our patients, we did not monitor serum level of vitamin $\mathrm{D}$, but in both groups patients had vitamin $\mathrm{D}$ therapy in high percentage.

\section{CONCLUSION}

In our study, that included patients with chronic kidney disease not on dialysis, about $10 \%$ had bone fractures in a two-year follow-up period, which is high percentage in a quite short follow-up period. Patients who developed bone fractures also had higher PTH serum level at the beginning of the monitoring, as well as after two-year follow-up (which was statistically significant), despite vitamin D supplementation therapy, so we can assume that they had a high-bone turnover disease.

The limitation of this study was that we have not determined bone specific alkaline phosphatase and DEXA, but on the other hand, it would not help in distinction of bone disease type. In that sense, bone biopsy remains a gold standard, although being an invasive method. On the other hand, FRAX score assessment could be a good tool in the estimation of bone fracture risk in patients with CKD in a long-term follow-up period.

Also, we want to underline that patients with CKD should be evaluated in terms of early detection of mineral and bone disorder, in order to prevent bone fractures.

Conflict of interest: The authors declare that there are not conflicts of interest. The results of this manuscript have been presented as oral presentation by Dr. Andreja Figurek at the Symposium "Bone in CKD", that was held in Amsterdam, 23 Sept 2016 (endorsed by ERA EDTA, CKD-MBD working group). Dr. Figurek won travel grant to the Symposium from ERA-EDTA.

Introducere. Osteodistrofia renală este o complicație severă a bolii cronice de rinichi (CKD) care creşte morbiditatea şi mortalitatea la aceşti pacienți. Tulburările mintale şi osoase încep de la debutul CKD şi afectează incidența fracturilor osoase. Scopul acestui studiu a fost de a observa frecvența diferitelor fracturi osoase la pacienții cu CKD care nu sunt dializați.

Metode. Acest studiu de grup a inclus 68 de pacienți, care au fost urmăriți pe o perioadă de doi ani. Pacienții au fost împărțiți în două grupe: una care a dezvoltat fracturi osoase, iar cealaltă nu a făcut-o. Au fost 35 (51,5\%) bărbați şi 33 (48,5\%) femei. Vârsta medie a pacienților a fost de 62,88 $\pm 11,60$ ani. În timpul monitorizării, s-au măsurat indicatori minerali şi osoşi. Au fost utilizate metode statisticie descriptive şi analitice pentru a analiza datele obținute.

Rezultate. In timpul acestui studiu de doi ani, şapte pacienți au prezentat fracturi osoase. Dintre acestea, au fost mai multe femei (6 pacienți) comparativ cu bărbați (doar 1 pacient). Cele mai frecvente au fost fracturile antebrațului. Nivelul 
mediu al hormonului paratiroidian (PTH) la începutul monitorizării a fost mai mare în grupul de pacienți cu fracturi osoase $(165,25 \pm 47,69 \mathrm{pg} / \mathrm{mL})$ față de celălalt grup $(103,96 \pm 81,55 \mathrm{pg} / \mathrm{ml})$. După o perioadă de urmărire de doi ani această diferență a devenit statistic semnificativă $(p<0,05)$. Pacienții care au dezvoltat fracturi osoase au avut un scor FRAX mai mare (folosit pentru evaluarea riscului de fractură).

Concluzie. In studiul nostru, aproximativ 10\% dintre pacienți au prezentat fracturi osoase in perioada de urmărire de doi ani. Pacienții care au dezvoltat fracturi au avut un nivel mai ridicat al PTH şi un scor FRAX mai mare.

Correspondence to: Andreja Figurek, MD, Akademika Jovana Surutke 978000 Banja Luka

Republic of Srpska, Bosnia and Herzegovina

Phone: 0038765668 626, Fax: 0038751660040

E-mail: andrejafigurek@yahoo.com

\section{REFERENCES}

1. KDIGO clinical practice guideline for the diagnosis, evaluation, prevention, and treatment of Chronic Kidney Disease-Mineral and Bone Disorder (CKD-MBD). Kidney Int Suppl. 2009 (113):S1-130.

2. EKNOYAN G., LAMEIRE N., BARSOUM R., ECKARDT KU., LEVIN A., LEVIN N., et al. The burden of kidney disease: improving global outcomes. Kidney Int.2004; 66 (4):1310-4.

3. ANPALAHAN M., VENKATESAN S., ANPALAHAN A. Fragility fractures in chronic kidney disease: assesment and pharmacologic management. Advances in Nephrology. vol. 2014, Article ID 727135, 7 pages, 2014. doi:10.1155/2014/727135.

4. HAMDY NA., KANIS JA., BENETON MN., BROWN CB., JUTTMANN JR., JORDANS JG., et al. Effect of alfacalcidol on natural course of renal bone disease in mild to moderate renal failure. BMJ. 1995; 310:358-63.

5. OZMEN B. Use of bisphosphonates in chronic kidney disease. World J Nephrol Urol. 2012; 1 (1):1-7.

6. Fracture Risk Assessment Tool. Centre for Metabolic Bone Diseases, University of Sheffield, UK. Available from: https://www.sheffield.ac.uk/FRAX/tool.aspx? country=9.

7. NICKOLAS TL., LEONARD MB., SHANE E. Chronic kidney disease and bone fracture: a growing concern. Kidney Int. 2008; 74 (6):721-31.

8. ALEM AM, SHERRARD DJ, GILLEN DL, WEISS NS, BERESFORD SA, HECKBERT SR, et al. Increased risk of hip fracture among patients with end-stage renal disease. Kidney Int 2000; 58:396-9.

9. COCO M., RUSH H. Increased incidence of hip fractures in dialysis patients with low serum parathyroid hormone. Am J Kidney Dis 2000; 36:1115-21.

10. NICKOLAS TL., MCMAHON DJ., SHANE E. Relationship between moderate to severe kidney disease and hip fracture in the United States. J Am Soc Nephrol. 2006; 17:3223-32.

11. ROBBINS J., ARAGAKI AK., KOOPERBERG C., WATTS N., WACTAWSKI-WENDE J., JACKSON RD., et al. Factors associated with 5-year risk of hip fracture in postmenopausal women. JAMA2007; 298: 2389-98.

12. DEYL V., FARRAH TE., TRAYNOR JP., SPALDING EM., ROBERTSON SE., GEDDES CC. Symptomatic fracture risk in the renal replacement therapy population. Nephrol. Dial. Transplant. (2016). doi: 10.1093/ndt/gfw222.

13. AYUS JC., FUENTES NA., NEGRE AL., MORITY ML., GIUNTA DH., KALANTAR-ZADEH K., et al. Mild prolonged chronic hyponatremia and risk of hip fracture in the elderly. Nephrol. Dial. Transplant. (2016). doi: 10.1093/ndt/gfw029.

14. RIX M., ANDREASSEN H., ESKILDSEN P., LANGDAHL B., OLGAARD K. Bone mineral density and biochemical markers of bone turnover in patients with predialysis chronic renal failure. Kidney Int. 1999; 56:1084-1093.

15. RUSSO CR., TACCETTI G., CANEVA P., MANNARINO A., MARANGHI P., RICCA M. Volumetric bone density and geometry assessed by peripheral quantitative computed tomography in uremic patients on maintenance hemodialysis. Osteoporos Int. 1998; 8:443-8.

16. JAMAL SA., GILBERT J., GORDON C., BAUER DC. Cortical pQCT measures are associated with fractures in dialysis patients. J Bone Miner Res. 2006; 21:543-8.

17. MAGNUSSON P., SHARP CA., MAGNUSSON M., RISTELI J., DAVIE MW., LARSSON L. Effect of chronic renal failure on bone turnover and bone alkaline phosphatase isoforms. Kidney Int 2001; 60:257-65.

18. MARUYAMA Y., TANIGUCHI M., KAZAMA JJ., YOKOYAMA K., HOSOYA T., YOKOO T., et al. A higher serum alkaline phosphatase is associated with the incidence of hip fracture and mortality among patients receiving hemodialysis in Japan. Nephrol Dial Transplant. 2014; 29:1532-8.

19. SARDIWAL S., MAGNUSSON P., GOLDSMITH DJ., LAMB EJ. Bone alkaline phosphatase in CKD-mineral bone disorder. Am J Kidney Dis 2013; 62:810-22.

20. PARK JC., KOVESDY CP., DUONG U., STREJA E., RAMBOD M., NISSENSON AR., et al. Association of serum alkaline phosphatase and bone mineral density in maintenance hemodialysis patients. Hemodial Int 2010; 14:182-92.

21. LERTDUMRONGLUK P., LAU WL., PARK J., RHEE CM., KOVESDY CP., KALANTAR-ZADEH K. Impact of age on survival predictability of bone turnover markers in hemodialysis patients. Nephrol Dial Transplant 2013; 28:2535-45. 
22. KOVESDY CP., URECHE V., LU JL., KALANTAR-ZADEH K.Outcome predictability of serum alkaline phosphatase in men with pre-dialysis CKD. Nephrol Dial Transplant 2010; 25:3003-11.

23. JADOUL M., ALBERT JM., AKIBA T., AKIZAWA T., ARAB L., BRAGG-GRESHAM JL., et al. Incidence and risk factors for hip or other bone fractures among hemodialysis patients in the Dialysis Outcomes and Practice Patterns Study. Kidney Int 2006; 70:1358-66.

24. QI Q., MONIER-FAUGERE MC., GENG Z., MALLUCHE HH. Predictive value of serum parathyroid hormone levels for bone turnover in patients on chronic maintenance dialysis. Am J Kidney Dis. 1995; 26(4):622-31.

25. TORRES A., LORENZO V., HERNANDEZ D., RODRIGUEZ JC., CONCEPCION MT., RODRIGUEZ AP., et al. Bone disease in predialysis, hemodialysis, and CAPD patients: evidence of a better bone response to PTH. Kidney International.1995; 47 (5):1434-42.

26. IIMORI S., MORI Y., AKITA W., KUYAMA T., TAKADA S., ASAI T., et al. Diagnostic usefulness of bone mineral density and biochemical markers of bone turnover in predicting fracture in CKD stage 5D patients - a single-center cohort study. Nephrol Dial Transplant 2012; 27:345-51.

27. LIN JH. Bisphosponates: a review of their pharmacokinetic properties. Bone. 1996; 18(2):75-85.

28. CONTR P., GUARNERI V. Safety of intravenous and oral bisphosphonates and compliance with dosing regimen. The Oncologist.2004; 9 (Suppl 4): 28-37.

29. SHERRARD DJ., HERCZ G., PEI Y., MALONEY NA., GREENWOOD C., MANUEL A., et al. The spectrum of bone disease in end-stage renal failure-an evolving disorder. Kidney Int. 1993; 43(2):436-42.

30. LEVIN A., BAKRIS GL., MOLITCH M., SMULDERS M., TIAN J., WILIAMS LA., et al. Prevalence of abnormal serum vitamin D, PTH, calcium, and phosphorus in patients with chronic kidney disease: results of the study to evaluate early kidney disease. Kidney Int. 2007; 71:31-8.

Received April 11, 2017 